International Journal of Instruction e-ISSN: 1308-1470 • www.e-iji.net

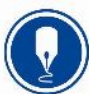

October $2019 \bullet$ Vol.12, No.4

p-ISSN: 1694-609X

pp. $733-746$

Received: 18/03/2019

Revision: 09/07/2019

Accepted: 14/07/2019

OnlineFirst:12/09/2019

\title{
Writing Anxiety among Indonesian EFL Students: Factors and Strategies
}

\section{Umiati Jawas}

Universitas Kanjuruhan Malang, Indonesia,umiati_jawas@unikama.ac.id

Writing anxiety is a term for a wide variety of apprehensive and pessimistic feelings about writing. The purpose of this study is to identify factors contributing to writing anxiety experienced by EFL students in writing essays and the strategies they apply to manage it. The possible factors of the anxiety were elaborated into close-ended questionnaire items that were distributed to the sampled students followed by open-ended questionnaire item on strategies to deal with the anxiety. The findings indicate that from several potentially anxiety producing factors of essay writing, essay assignment that must be done in the class is the most dominant factor of writing anxiety experienced by the students. Collaborative works in pairs or small groups for idea development and essay construction are the common strategies adopted to minimize the anxiety. The findings imply that when students are given the opportunity to use the preferred strategies, their writing anxiety can be manageable.

Keywords: reign language anxiety, writing anxiety, Indonesian EFL students, English essays, EFL

\section{INTRODUCTION}

Anxiety in foreign language learning has attracted many scholars to investigate it (Abdullah, Hussin, \& Shakir, 2018; Blasco, 2016; Daud, Daud, \& Kassim, 2005; Stewart, Seifert, \& Rolheiser, 2015; Ho, 2016; Jalili \& Shahrokhi, 2017; Kirmizi \& Kirmizi, 2015; Negari \& Rezaabadi, 2012; Shang, 2013). Empirical studies on foreign language anxiety suggests that students experience some sort of anxiety when they are engaged in learning a foreign language and scholars have agreed that anxiety does have a relation with foreign language mastery (Abdullah, Hussin, \& Shakir, 2018; Blasco, 2016; Cheng, 2002; Daud, Daud, \& Kassim, 2005; Stewart, Seifert, \& Rolheiser, 2015; Ho, 2016; Jalili \& Shahrokhi, 2017; Kirmizi \& Kirmizi, 2015; Negari \& Rezaabadi, 2012; Riasati, 2011; Schmidt, 2004). It is one of the affective factors that determines successful language performance (Andrade \& Williams, 2009; Daud, Daud, \& Kassim, 2005; Field, 2004; Gregersen \& Horwitz, 2005; Kirmizi \& Kirmizi, 2015; Tuncay \& Uzunboylu, 2010). Studies on effect of anxiety on foreign language learning have revealed negative effect of anxiety on English as a Foreign Language (EFL) students' performance (Andrade \& Williams, 2009; Gregersen \& Horwitz, 2005; Kirmizi \& 
Kirmizi, 2015). The findings of their studies show that language anxiety felt by EFL students can block their language competence cognitively and socially (Daud, Daud, \& Kassim, 2005; Jalili \& Shahrokhi, 2017; Kirmizi \& Kirmizi, 2015; Ho, 2016). Horwitz et al (1986) claimed that students who experience language anxiety tend to study harder but the level of their learning achievement does not correspond with the effort they put into it.

Much subsequent research has been conducted to investigate the relevance of foreign language anxiety particularly in students' writing performance. The growing research interest in writing anxiety may due to its gained importance in foreign language learning (Abdullah, Hussin, \& Shakir, 2018; Blasco, 2016; Cheng, 2002; Cheng, 2004; Daud, Daud, \& Kassim, 2005; Stewart, Seifert, \& Rolheiser, 2015; Ho, 2016; Jalili \& Shahrokhi, 2017; Kirmizi \& Kirmizi, 2015; Rahim, Jaganathan, \& Mahadi, 2016). Empirical studies on the skill categorization in foreign language learning have led to an agreement that neither oral nor written language is characteristically superior to the other, but they are different in terms of textual features, socio-cultural norms and patterns of use, and the cognitive processes involved in language production and comprehension (Weigle, 2002). This likely has made research on writing anxiety attract many scholars particularly in investigating its relevance in foreign language learning (Abdullah, Hussin, \& Shakir, 2018; Blasco, 2016; Daud, Daud, \& Kassim, 2005; Stewart, Seifert, \& Rolheiser, 2015; Ho, 2016; Jalili \& Shahrokhi, 2017; Kirmizi \& Kirmizi, 2015; Negari \& Rezaabadi, 2012; Schmidt, 2004).

\section{REVIEW OF LITERATURE}

Writing anxiety is a persistent feeling of not being ready to write or not being good enough to write. According to Hjortshoj (2001), anxiety in writing is a wide variety of apprehensive and pessimistic feelings about writing. However, these feelings do not pervasively characterize a person's writing life and it is naturally situational (Hjortshoj, 2001). As writing anxiety does not describe psychological attributes, students are likely to experience the anxiety in particular contexts caused by their negative or difficult experiences with writing (Al-Sawalha \& Chow, 2012; Hjortshoj, 2001). It is a common fact that writing in foreign language is perceived as a difficult task among EFL students (Blasco, 2016; Cheng, 2002; Daud, Daud, \& Kassim, 2005; Kurt \& Attay, 2007; Latiff, 2007; Lee, 2005). However, some problems experienced by EFL students in writing are related to their distinctive English language competence that is greatly influenced by their competence in their own native language (Silva, 1993).

Writing anxious students may experience higher anxiety when asked to write and the anxiety can be seen from their behaviors, attitudes, and written work (Cheng, 2002; Jebreil et al, 2015; Rahim \& Hayas, 2014; Smith, 2004). In terms of written work, writing anxious students tend to have more difficulty in stating writing goals and organizing ideas, producing shorter and fewer words, making many errors in the composition, and using inappropriate grammatical and rhetorical conventions and lexical variety (Al-Shboul \& Huwari, 2015; Kirmizi \& Kirmizi, 2015; Smith, 2004; Silva, 1993). The difficult or even stressful writing experiences faced by EFL students may vary from one student to the other. However, there are some common causes such 
as adjusting to a new form of writing, writing for overly critical or demanding readers, remembering negative criticism on their writing in the past, working with limited time or with a lot of unstructured time (Hjortshoj, 2001; Ho, 2016; Kirmizi \& Kirmizi, 2015).

Research on writing anxiety has thrown some conflicting evidences of the impact of anxiety on writing ability. Some scholars believe that writing anxiety plays an important role in writing ability as it triggers students' concentration and accuracy (Brown, 2007; Lehrer, Goldman, \& Strommen, 1990). However, other scholars think that students should not be exposed to anxiety as it may adversely interfere with the development of their writing skills (Negari \& Rezaabadi, 2012). Accumulating evidence has revealed that anxiety leads to lower writing performance (Lee, 2002; Rezaei, Jafari, \& Younas, 2014; Shang, 2012; Shang, 2013). In addition, different studies in language teaching have confirmed that anxiety may unfavorably obstruct with the development of student writing skills and lead to lower writing performance (Negari \& Rezaabadi, 2012; Shang, 2013).

On the contrary, there are some scholars who believe that moderate writing anxiety can improve EFL students' writing ability (Brown, 2007; Negari \& Rezaabadi, 2012). Such facilitative anxiety can help students cope with the writing assignment. Empirical studies have shown that EFL students who experience anxiety in writing will concentrate more; thus, will write more accurately (Brown, 2007; Lehrer, Goldman, \& Strommen, 1990). Concentration and accuracy in writing are among the contributing factors for better writing performance (Negari \& Rezaabadi, 2012). In their research Negari and Rezaabadi (2012) found that students with higher level of anxiety performed better in all aspects of their writing assignment. Such finding strengthens the dichotomy of the role of anxiety in student's writing performance. This contrasting effect of writing anxiety makes it a fascinating topic to examine.

This study was conducted to identify factors contributing to writing anxiety experienced by Indonesian university students in writing essays. Essay writing is a very typical academic writing for students in university level. In writing an essay, a writer actually states an argument on a selected topic academically. Therefore, writing an essay is quite a demanding and complex task. In Indonesian schools and universities, writing has been the most neglected skill (Alwasillah, 2004). Such condition is prompted by the exclusion of writing in the concept of literacy. Literacy is perceived more as the ability to read than the ability to read and write (Alwasillah, 2000). Moreover, teaching of writing emphasizes more on writing theories and grammar rather than expression of ideas (Alwasillah, 2000). The findings of this study are expected to reveal factors that play a role in producing writing anxiety among Indonesian students when composing essays. In addition, the study also investigated strategies implemented by the students to reduce the anxiety. The identification of the strategies could provide information on how to minimize the occurrence of writing anxiety.

\section{METHOD}

This study was designed in quantitative descriptive research. The data were collected through questionnaire distribution to the sampled respondents. The respondents of this 
research were 80 university students of English Department from four parallel Essay Writing classes.

The questionnaire was divided into two sections. The first section was developed based on five categories consisting of prompt leading questions, essay writing process, type of essay assignment, and classroom atmosphere. These categories were then elaborated into potential factors that that could lead to the occurrence of writing anxiety (see Table 1). The items were constructed in closed-ended and adapted Likert scaled-format. This format was chosen to ease the participants in providing responses and also to ease the calculation and description of the collected responses later on.

The responses of each questionnaire item were tallied and calculated to see the frequency of the responses chosen by the respondents. The frequency of the chosen response was calculated to find the mean then altered into percentage and would be used to identify factors contributing to the experience of writing anxiety when composing essays. The results of these simple statistical calculations were used to analyze the data and draw the conclusion.

The second section of the questionnaire was constructed in open-ended format to identify possible strategies students use in handling their writing anxiety. Slightly different way was taken to analyze the strategies applied by the students in managing their writing anxiety. All the reported strategies were identified and listed. Similar strategies were grouped together while still acknowledging different reasons for the chosen strategies to provide comprehensive description of how the anxiety was managed by the respondents.

Table 1

Questionnaire Item Category

\begin{tabular}{lll}
\hline No & Category & Factors Causing Writing Anxiety \\
\hline 1 & Prompt Leading Questions & Student's knowledge of how to write essay \\
& & Student's perception of essay writing \\
& & Student's readiness to write essay \\
& Student's feeling of anxiety when writing \\
\hline 2 & Essay Writing Process & Deciding the thesis statement \\
& & Building argumentative ideas \\
& Developing essay content \\
& Sequencing ideas for essay content \\
& Deciding supporting data for essay content \\
\hline 3 & Type of Essay Assignment & Drawing the conclusion \\
& In-class assignment \\
& Take-home assignment \\
& Individual assignment \\
& Pair assignment \\
& Team assignment \\
& Topic decided by lecturer \\
& Topic decided individually \\
& Topic decided by pair \\
& Topic decided by team \\
& Time-restricted assignment \\
\hline 4 & Classroom Atmosphere & Peer competition \\
& Lecturer's teaching style \\
\hline &
\end{tabular}




\section{FINDINGS}

Similar to the questionnaire format, the presentation of the findings begins with the findings of the first section of the questionnaire and will follow the category and the listed factors causing writing anxiety as seen in Table 1. While the findings of the second section on the used strategies to manage writing anxiety will be presented in the later part.

\section{Prompt Leading Questions}

The questions were intended to provide general description of how the respondents thought about essay writing. The result shows that in average the students have quite sufficient knowledge to write a good essay (76.47\%). Although, the students stated that they had the knowledge to write an essay, $67.64 \%$ of the students claimed that essay writing was not easy for them. Then, the students were asked about their readiness to write an essay. $55.88 \%$ of them said they were quite ready and only $5.88 \%$ of them claimed to be very ready. The students were also asked whether they felt anxious every time they had to write an essay. The answer reveals that the majority of them (67.64\%) told that they were quite anxious.

Conclusively, it can be said that although students, in average, possessed quite sufficient knowledge of essay writing, they considered essay writing as not an easy task and they were not ready every time they wrote an essay. Therefore, they felt quite anxious whenever they had to compose an essay.

\section{Factors Causing Anxiety during Essay Writing Process}

The prompt leading questions were then followed by the questionnaire items specifically designed to know the factors causing writing anxiety when students composed an essay. The first identified factors were dealing with process of essay writing and the students were asked to rate the level of anxiety they felt during the process from the most anxious to the least anxious and the results showed that there were three most anxious processes of essay writing that the students felt: when they had to arrange ideas to develop the content of the essay $(41.17 \%)$ followed by when they had to decide the thesis statement of their essay $(26.47 \%)$, and when they had to develop the content of the essay $(17.67 \%)$. The three least anxious processes of essay writing that the students felt were when they made the conclusion of the essay $(52.94 \%)$, when they had to find the supporting data for the essay content (5.88\%), and when they had to find the thesis statement of the essay (5.88\%). The complete responses were shown in Figure 1 below: 


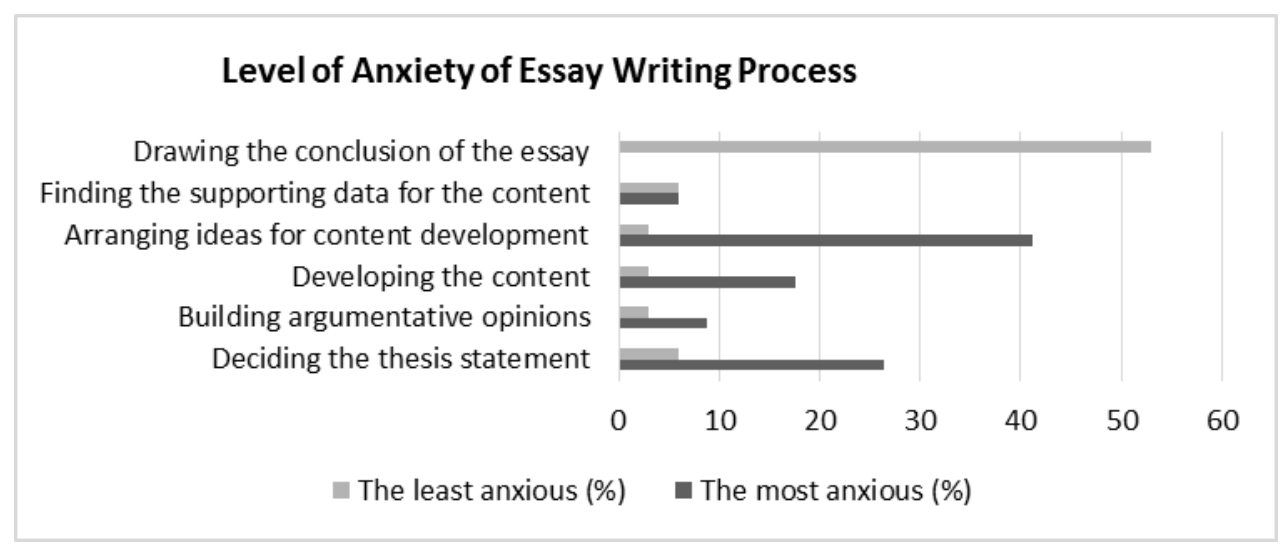

Figure 1

Level of Anxiety of Essay Writing Process

It can be inferred that arranging ideas for essay content development is the most likely essay writing process that creates higher level of anxiety to the students compared to the other essay writing process. While drawing the conclusion of the essay is the least likely to produce level of anxiety to the students.

\section{Types of Essay Assignment Causing Anxiety}

The next questions were to know the anxiety felt by the students in accordance with the type of essay assignment that they dealt with. The responses indicate that $88.23 \%$ of the students felt more anxious when the assignment was in the form of in-class assignment. The next question asked whether individual task, pair task, or group task created the most anxious feeling to the students. The responses show that essay assignment in the form of individual task was the one that made them most anxious (64.70\%).

Another question was to find out the topic decision for essay writing that created the most anxious feeling to the students. The topic decision was divided into topic decided by lecturer, topic decided individually, topic decided by pair, and topic decided by group. The result showed that $67.64 \%$ of the students said that if it was a lecturerdecided topic.

The last question item related to the type of essay assignment was on whether timerestricted essay assignment produced the anxiety to the students. $70.58 \%$ of them agreed that time-restricted essay assignment made them feel anxious.

In conclusion, types of essay assignments that potentially cause the students to feel most anxious are that of individual essay assignment done in the class with the topic decided by the lecturer and within time restriction.

\section{Classroom Atmosphere Causing Writing Anxiety}

There were two questions dealing with the factors of anxiety caused by classroom atmosphere. They were the lecturer and peer competition. The responses reveal that the 
majority of the students felt that their lecturer made them feel quite anxious $(61.76 \%)$. For peer competition, half of the respondents $(50 \%)$ said that their classmates did not make them feel anxious.

From the answers above, it can be said that the lecturer is the one of the classroom atmospheres factors that is likely to produce anxiety to the students while their classmates have equal chance to cause them to feel anxious or not.

\section{The Most Dominant Factor That Causes Writing anxiety}

From the responses of the students to the questionnaire items, there were some factors that potentially to produce higher level of anxiety to the students when they had to compose an essay as seen by the higher percentage of each response for each questionnaire item as compiled in the following Figure 2:

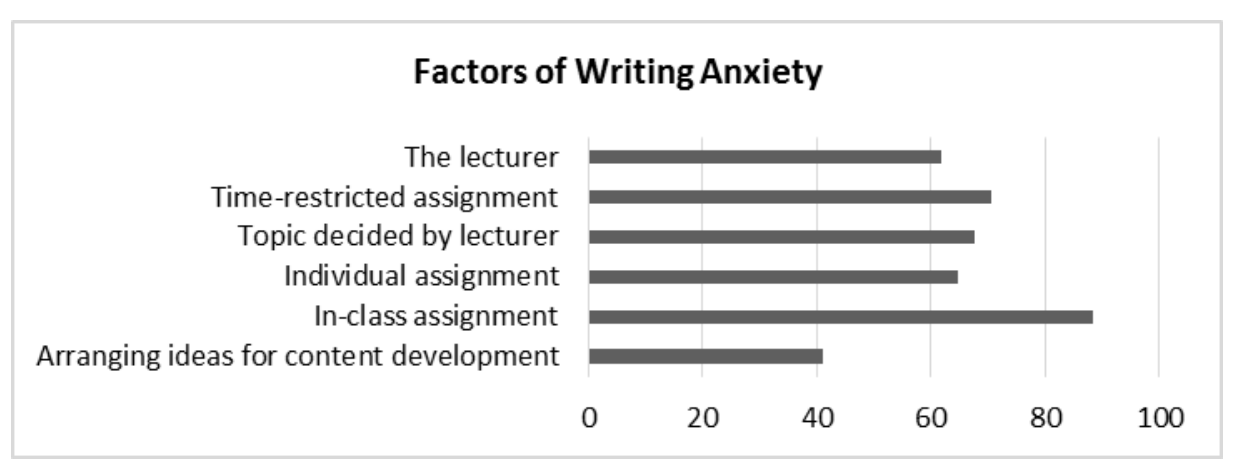

Figure 2

Writing anxiety Factors

From Figure 2, it reveals that from those potentially anxiety producing factors of essay writing, essay assignment that must be done in the class is the most dominant factor of writing anxiety experienced by the students $(88.23 \%)$. The second highest percentage of the responses is on time-restricted assignment since in-class assignment is usually done in a time-limited period. Conclusively, in-class essay assignment is the most dominant factor that causes writing anxiety to the students.

\section{The Strategies to Manage Writing Anxiety}

The open-ended questionnaire on the strategies the respondents applied when experiencing writing anxiety revealed the following strategies. The first strategy is developing essay outline. This strategy was used to help in developing and sequencing the ideas because the outline could give the frame of the essay and it could ease the whole process of essay writing. Outline could also help the students to have a firm format of their idea development and to stay focused.

The second strategy is building better background knowledge on the essay topic. Students stated that they were really anxious when they had no idea or only partially knew of what to write about. This lack of background knowledge had been seen as the 
hurdle to write the essay. Therefore, the strategy they used to handle this problem was by expanding and enriching their knowledge background mainly through reading and brainstorming. The students did the brainstorming with their classmates either during learning hour if they were permitted to have group brainstorming or after class hour usually with the classmates who lived in the same boarding house or who joined similar student extracurricular organization.

The third strategy is finding supporting references. This strategy was done usually within the process of writing when the students were stuck with their essay development. Actually, they had already decided the scope of their essay but were slowed down because of the shortage of supporting references. The main material that they looked for could be from any written sources but mainly from unpublished theses.

The fourth strategy is making some pauses during the writing process. To cope with writing anxiety during the composition process, students stated that taking a few pauses for a few minutes really helped them to lessen their anxiety. These pauses also helped them to feel refreshed. The students added that after the pauses they were energized and could continue their writing. The students did not do something special during the pauses; they usually just took deep breath, looked outside, stretched their body, or simply did nothing.

The fifth strategy is taking breaks. If pauses were done only for a very short period of time, breaks were done for a longer period of time and one-day break was considered enough for the students. If the break was longer, the students were afraid that they would lose their ideas. During the breaks the students tried not to think about the assignment and only revived their mind. They stated that this temporary unawareness of the assignment would give them better idea for the revision later on since they could identify the shortages of their writing easier if their mind was not too preoccupied with the assignment.

The sixth strategy is discussing the problems with peer students or seniors. This strategy is essentially similar to strategy number 2: building background knowledge of the essay topic through brainstorming. The difference was only the number of people involved in the process. This strategy was usually done with an individual rather than a group of people. This strategy was valued to be more convenient since the students could talk more freely and confidently since the person, they chose was the one that they trusted and was closer with.

The seventh strategy is discussing the problems with the lecturer. Although this strategy was less popular compared to the other strategies, the students found that it could benefit them to use this strategy especially if it dealt with the clarification and some important emphasis of the assignment. However, they found it discouraging to discuss the content of their essay to the lecturer simply because they were embarrassed and afraid that the lecturer would not be helpful and became too critical.

The last strategy is trying to stay focused and calm. This strategy was sort of accompanying strategy to the other strategy and was done simultaneously with the strategies above. Although the students found that time-restricted assignment was very 
demanding and mind-draining, they still tried to be focused and calm because it could help them to concentrate on their essay writing.

\section{DISCUSSION}

The findings of this study underline some important points that should be taken into consideration if student's writing achievement is to be accomplished. Although some findings are not something that totally new to know; however, this acknowledgement is often neglected especially by the lecturer. Many times, writing anxiety is valued as writing challenge. Therefore, difficulties are not treated properly and assumed to be the trigger of better writing outcomes. This notion should be carefully examined since writing anxiety can potentially lead to poor writing achievement and its dispiriting effect can be substantially harmful especially academically (Al-Shboul \& Huwari, 2015; Atay \& Kurt, 2007; Daud, Daud, \& Kassim, 2005; Field, 2004; Ho, 2016; Rezaei, Jafari, \& Younas, 2014; Jebreil, Azizifar, Gowhary \& Jamalinesari, 2015).

It is a common fact that students are easily shut down if they perceive and are perceived to be academically poor. Writing anxiety is not the signal of writing failure but it is simply a condition that if not treated properly can lead to unsatisfactory writing accomplishment (Cheng, 2002; Jebreil, Azizifar, Gowhary \& Jamalinesari, 2015). In other word, it can be said that writing anxiety is more or less like symptoms. When the symptoms are better treated, the unexpected situation can be avoided. Therefore, lecturer and students as well need to identify the possible causes of writing anxiety and take proper caution to lessen and even eliminate the potential results of this writing anxiety. As the definition says writing anxiety is generally not pervasive in a person's writing life and it is naturally situational (Hjortshoj, 2001: 7). In addition, writing anxiety does not describe psychological attributes and students experience writing anxiety in particular contexts. From this description, it can be concluded that if the possible causes of writing anxiety are identified and taken care of, writing achievement can be then reached and its reward has the most significant influence to student's overall writing performance.

From students' responses on the factors that could make them experience writing anxiety, lecturer can adapt their form of essay writing assignment or at least select what type of assignment to be done by the students as long as it is in accordance with the course objectives and appropriate with the condition of the students (Cao, 2011; Stewart, Seifert, \& Rolheiser, 2015; Rahim, Jaganathan, \& Mahadi, 2016). It does not mean that the assignments that have higher chance to create writing anxiety must be totally avoided but more to what strategies to be employed to decrease the unexpected effects of this type of assignment to student writing achievement. As revealed by the findings of this research, students did have strategies to deal with this writing anxiety. As long as they are given opportunity to use the strategies, they can survive and pass from the threat of this writing anxiety.

Writing has been perceived as the most difficult skill to master (Blasco, 2016; Daud, Daud, \& Kassim, 2005; Kurt \& Atay, 2007; Latiff, 2007) and writing an essay is a complex task. Therefore, it is realistic if the students said that they were anxious to do 
the assignment in class especially within a limited time frame. It is a common fact that fast writing is not something easy to accomplish. Even a well-experienced writer can find it as a truth. Although regular practices can speed up the time needed to finish a composition, still it is not an easy accomplishment. If it is not for a test purposes, timerestricted essay composition should not be too much demanded from the students. What should be of importance to the lecturers is to minimize the level of anxiety experienced by the students. The lower the level of anxiety, the better the students will perform in their essay assignment (Stewart, Seifert, \& Rolheiser, 2015; Hassan, 2001). Lower level of writing anxiety can also boost students' confidence in writing (Blasco, 2016; Daud, Daud, \& Kassim, 2005; Rahim, Jaganathan, \& Mahadi, 2016).

The next findings of this research also indicate that brainstorming and class discussions either in peer or group should be part of the teaching and learning process. These strategies of collaborative learning has been found to have a significant effect on students' writing competence (Abdullah, Hussin, \& Shakir, 2018; Brown, 2008; Swain, 2010). Collaborative learning can provide peer support to the students to develop and arrange ideas for essay composition. Having other person's opinions on the topic of the essay can broaden and widen the perspectives on the topic and therefore can enrich the content and speed up the composition process. Although essay is basically about personal expression but working in groups can improve students' writing knowledge and creativity (Abdullah, Hussin, \& Shakir, 2018; Jalili \& Shahrokhi, 2017; Yong, 2006). Brainstorming and class discussions can also boost self confidence in expressing ideas since this kind of collaborative learning will create a supporting and stress-free atmosphere in the class (Abdullah, Hussin, \& Shakir, 2018; Jalili \& Shahrokhi, 2017; Rahim, Jaganathan, \& Mahadi, 2016).

Another important reflection on the findings of this research is on the role of the lecturers in producing writing anxiety to the students. In Indonesian context, lecturers or teachers are entitled with high authority (Azra, 2002; Tilaar, 2009). This cultural power can produce an invisible distance between teachers and students; therefore, it can discourage an exchange of ideas between them. It is very common to find an akward and hesitant relationship during classroom activities. In addition to this cultural gap, lecturers and their teaching style can be the determining factor to students' writing competence (Abdullah, Hussin, \& Shakir, 2018; Cao, 2011; Kara, 2013; Kirmizi \& Kirmizi, 2015; Rezaei \& Jafari, 2014). Open communication with the students can close the gaping hole between the two and decrease the hesitation from the students to talk and discuss the problems (Bekleyen, 2004). Lecturer is recommended to provide the time for the students at least by encouraging students to ask questions and express their concerns and thoughts during class session. Such approach will create a tension- free classroom atmosphere and subsequently will eliminate students' writing anxiety (Abdullah, Hussin, \& Shakir, 2018; Kirmizi \& Kirmizi, 2015; Rahim, Jaganathan, \& Mahadi, 2016).. Lecturer should also clearly set the expectation of the outcome so the students do the assignment in the guided path. The clear expectation can also eliminate the ambiguity and confusion about how students are going to be measured for their writing accomplishment. 


\section{CONCLUSION}

The findings of this study show that although students, in average, possessed quite sufficient knowledge of essay writing, they considered essay writing as not an easy task and they were not ready every time they wrote an essay. Therefore, they felt quite anxious whenever they had to compose an essay. Arranging ideas for essay content development was the most likely essay writing process that created higher level of anxiety to the students compared to the other essay writing process. Types of essay assignments that potentially caused the students to feel most anxious were that of individual essay assignment done in the class with the topic decided by the lecturer and within time restriction. It also showed that the lecturer was the one of the classroom atmospheres factors that was likely to produce anxiety to the students while their classmates had equal chance to cause them to feel anxious or not.

Reflecting on the findings of this study, it is recommended that writing lecturers to alternate assignment of the potentially anxiety producing and that of less intimidating to students. Since writing anxiety is not something to avoid but something to manage with proper strategies, the level of anxiety can be reduced gradually and students can be accustomed to those types of assignment progressively. Writing lecturers should be able to create anxiety-free classroom atmosphere where students feel at ease when they have to write an essay. However, writing lecturer should also try to increase the writing speed of the students through the provision of gradually-time-restricted assignments. The likely cause of why students feel anxious with the time-limited assignments is not because of the shortage of their writing ability but more because of the lack of their experiences of such kind of assignment. Therefore, if they are trained to accomplish these assignments, they can be able to adapt themselves to write in designated time. Brainstorming and discussion are also needed to put into priority whenever an essay assignment is given because these two strategies can help students enrich their background knowledge and decide their writing framework of the given topic with the support from their peers.

Most importantly, students should be informed that writing anxiety is not the indication of poor writing ability but it is a possible condition that may occur during the writing process and when it is treated properly there is a possibility to get rid of this anxious feeling right away. Writing lecturers and students are required to be able to identify the potential causes of the occurrence of this writing anxiety and try to eliminate the effects of this writing anxiety on the students' writing competence. Although writing is perceived to be challenging, it should not be an anxiety-inducing activity. Students need to be encouraged to have a positive view at their essay writing assignment. As important, students need to be provided the time to apply their personal strategies to manage their writing anxiety.

\section{ACKNOWLEDGEMENT}

The writer of this article as the researcher in this study would like to thank Universitas Kanjuruhan Malang as this study was funded by Universitas Kanjuruhan Malang's internal research funding under the Decree Number: 100/C3/I.3/LPPM-UK/2016. The 
writer would also like to thank the students of Essay Writing Class First Semester of 2016/2017 for their participation in this study.

\section{REFERENCES}

Abdullah, M. Y., Hussin, S., \& Shakir, M. (2018). The Effect of peers" and teacher's feedback on writing anxiety level through CMC applications. International Journal of Emerging Technologies in Learning (iJET), 13(11), 196-207. doi: 10.3991/ijet.v13i11.8448.

Al-Sawalha, A. B. S., \& Chow, T. V. F. (2012). The effects of writing apprehension in English on the writing process of Jordanian EFL students at Yarmouk University. International Interdisciplinary Journal of Education, 1(1), 6-14.

Al-Shboul, Y., \& Huwari, I. F. (2015). The causes of writing apprehension through students' perspective. Journal of Language Teaching and Research, 6(3), 535-544. doi: 10.17507/jltr.0603.08.

Andrade, M., \& Williams, K. (2009). Foreign language anxiety in Japanese ELT universities classes: Physical, emotional, expressive and verbal reactions. Sophia Junior College Faculty Journal, 29, 1-24.

Aragao, R. (2011). Beliefs and emotions in foreign language learning. System, 39(3), 302-313. doi: 10.1016/j.system.2011.07.003.

Atay, D., \& Kurt, G. (2007). Prospective teachers and L2 writing anxiety. ASIAN EFL Journal, 8(4), 100-118.

Azra, A. (2002). Paradigma baru pendidikan nasional: rekonstruksi dan demokratisasi [New paradigm of national education: Reconstruction and democratization]. Jakarta, Indonesia: Penerbit Buku Kompas.

Batstone, R. (Ed.). (2010). Socio-cognitive perspective on language use and language learning. Oxford: Oxford University Press.

Bekleyen, N. (2004). The influence of teachers and peers on foreign language classroom anxiety. Retrieved from http://www.academia.edu/460876/The_Influence_of_Teachers_and_Peers_on_Foreign_ Language_Classroom_Anxiety.

Blasco, J. A. (2016). The relationship between writing anxiety, writing self-efficacy, and Spanish EFL students' use of metacognitive writing strategies: A case study. Journal of English Studies, 14, 7-45. doi: 10.18172/jes.3069.

Brown, H. D. (2007). Principles of language learning and teaching. White Plains, NY: Pearson.

Brown, F. A. (2008). Collaborative learning in the EAP classroom: Students' perceptions. Retrieved from http://www.esp-world.info/Articles_17/PDF/Collaborative learning.pdf. 
Cao, Y. (2011). Investigating situational willingness to communicate within second language classrooms from an ecological perspective. System, 39(4), 468-479. doi: 10.1016/j.system.2011.10.016.

Cheng, Y. S. (2002). Factors associated with foreign language writing anxiety. Foreign Language Annals, 35(6), 647-656. doi: 10.1111/j.1944-9720.2002.tb01903.x.

Cheng, Y. S. (2004). A measure of second language writing anxiety: Scale development and preliminary validation. Journal of Second Language Writing, 13(4), 313-335. doi: 10.1016/j.jslw.2004.07.001.

Daud, N. S. M., Daud, N. M., \& Kassim, N. L. A. (2005). Second language writing anxiety: Cause or effect? Malaysian Journal of ELT Research (MaJER), 1(1), 1-19.

Field, J. 2004. Psycholinguistics: The key concepts. Routledge, Taylor \& Francis Books Ltd.

Gregersen, T., \& Horwitz, E. (2002). Language learning and perfectionism: An anxious and non-anxious language learners' reactions to their own oral performance. The Modern Language Journal, 86(4), 562-570. doi: 10.1111/1540-4781.00161.

Hjortshoj, K. (2001). Understanding writing blocks. Oxford: Oxford University Press.

Ho, M. (2016). Exploring writing anxiety and self-efficacy among EFL graduate students in Taiwan. Higher Education Studies, 6(1), 24-39. doi: 10.5539/hes.v6n1p24.

Jalili, M. H., \& Shahrokhi, M. (2017). The effect of collaborative writing on Iranian EFL learners' 12 writing anxiety and attitudes. Journal of Applied Linguistics and Language Research, 4(2), 203-215.

Jebreil, N., Azizifar, A., Gowhary, H., \& Jamalinesari, A. (2015). A study on writing anxiety among Iranian EFL students. International Journal of Applied Linguistics \& English Literature, 4(2), 68-72. doi: 10.7575/aiac.ijalel.v.4n.2p.68.

Kara, S. (2013). Writing anxiety: A case study on students' reasons for anxiety in writing classes. Anadolu Journal of Educational Sciences International, 3(1), 103-111.

Kirmizi, O., \& Kirmizi, G. D. (2015). An investigation of L2 learners' self-efficacy, writing anxiety and its causes at higher education in Turkey. International Journal of Higher Education, 4(2), 57-66. doi: 10.5430/ijhe.v4n2p57.

Kurt, G., \& Atay, D. (2007). The effects of peer feedback on the writing anxiety of prospective Turkish teachers of EFL. Journal of Theory and Practice in Education, 3(1), 12-23.

Latiff, M. A. (2007). The factors accounting for the Egyptian EFL university students' negative writing affect. Essex Graduate Student Papers in Language \& Linguistics, $9(7), 57-82$. 
Negari, G. M., \& Rezaabadi, O. T. (2012). Too nervous to write? The relationship between anxiety and EFL writing. Theory and Practice in Language Studies, 2(12), 2578-2586. doi: 4304/tpls.2.12.2578-2586.

Rezaei, M. M., Jafari, S. M., \& Younas, M. (2014). Iranian EFL students' writing anxiety: Levels, causes and implications. English for Specific Purposes World, 42(15), $1-10$.

Riasati, M. J. (2011). Language learning anxiety from EFL learners' perspective. Middle-East Journal of Scientific Research, 7(6), 907-914.

Silva, T. (1993). Toward an understanding of the distinct nature of L2 writing: The ESL research and its implications. TESOL Quarterly, 27(4), 657-677. doi: 10.2307/3587400.

Steward, G., Seifert, T. A., \& Rolheiser, C. (2015). Anxiety and self-efficacy's relationship with undergraduate students' perceptions of the use of metacognitive writing strategies. Canadian Journal for the Scholarship of Teaching and Learning, 6(1), 1-17. doi: 10.5206/cjsotl-rcacea.2015.1.4.

Storch, N. (2011). Collaborative writing in L2 contexts: Processes, outcomes, and future directions. Annual Review of Applied Linguistics, 31(1), 275-288. doi: 10.1017/S0267190511000079.

Swain, M. (2010). Talking it through: Language as a source of learning. In R. Batestone (Eds.), Socio-cognitive perspectives on language use and language learning (pp. 112130). Oxford: Oxford University Press.

Tilaar, H. (2009). Membenahi pendidikan nasional [Fixing national education]. Jakarta, Indonesia: Penerbit Rineka Cipta.

Tuncay, N., \& Uzunboylu, H. (2010). Anxiety and resistance in distance learning. Cypriot Journal of Educational Sciences, 5(2), 142-150.

Weigle, S. Cushing. (2002). Assessing writing. United Kingdom: Cambridge University Press.

Young, D. J. (1991). Creating a low-anxiety classroom environment: What does language anxiety research suggest? The Modern Language Journal, 75(4), 426-439. doi: 10.2307/329492. 